\title{
Cytogenetic and clinical studies in gonadal dysgenesis with 46,X,Xt(qter $\rightarrow$ p221::p223 $\rightarrow$ qter) karyotype: review and phenotype/karyotype correlations
}

\author{
M FERRARO,* A DE CAPOA,* C MOSTACCI, * F PELLICCIA,* \\ P ZULLI, $\dagger$ M A BALDINI, $\dagger$ AND Q DI NISIO $\dagger$ \\ From the *Istituto di Genetica e Centro di Genetica Evoluzionistica del CNR, Università di Roma, Rome; and \\ $\uparrow$ †attedra di Clinica Ostetrica, Università "G D'Annunzio" Chieti, Italy.
}

SUMmaRY Chromosome analysis by $\mathrm{Q}, \mathrm{R}$, and $\mathrm{C}$ banding was performed in a case diagnosed clinically as gonadal dysgenesis and the karyotype was shown to be $46, X, X t$ tqter $\rightarrow$ p221::p223 $\rightarrow$ qter). Localisation of the breakpoints in the fused $\mathrm{X}$ chromosomes and replication studies have led to a hypothesis on the origin of the translocation. A comparison of clinical and cytogenetical findings in this and other published cases has also been made in an attempt to detect some phenotype/ karyotype correlations.

Cases of known $\mathrm{X} ; \mathrm{X}$ translocations in man are quite rare. Some of these, published before the introduction of banding techniques, have been described as known or presumptive $\mathrm{X} ; \mathrm{X}$ or $\mathrm{X}$; autosome translocations, mostly on the basis of the clinical picture. ${ }^{1}$

Since 1972, 12 more cases have been described and exhaustively studied by means of combined banding techniques, including one of the older cases $^{2}$ which has been studied again with modern banding techniques (table 1). ${ }^{3}$ The chromosomal characterisation of these new cases is often very accurate and includes the localisation of the breakpoints ${ }^{4}$ as well as hypotheses on the possible mechanisms of the chromosomal abnormality. ${ }^{5-7}$ Many cases, however, either lack sex chromatin studies and histological studies of gonadal tissues, or give rather scanty clinical and endocrinological pictures of the patients.

We present the case of an adult female, diagnosed clinically as a case of gonadal dysgenesis, in whom exhaustive clinical, endocrinological, histological, and cytogenetical studies have been performed.

\section{Case report}

CLINICAL FINDINGS

The patient, aged 22, was first referred to the Department of Obstetrics and Gynaecology of the University of Chieti because of amenorrhoea of 3 years' duration. She was the second born of seven children Received for publication 18 February 1980 of normal parents. All the sibs are phenotypically normal and in good health. There is no family history of amenorrhoea, spontaneous abortions, or congenital malformations.

The age of both parents at the time of birth was 23. Pregnancy and delivery were uneventful and birthweight was 3200 g. No lymphoedema was noted during early infancy. No feeding difficulties or major complications were noted during childhood. Menarche occurred at the age of 14; subsequent menstruation occurred only after steroid withdrawal until the age of 19. Secondary sex characteristics developed at the usual age. At the age of 19 isolated spontaneous bleeding was recorded. A laparoscopy, performed in another hospital, showed: "a small uterus and two ovaries of the size of small almonds". When first seen by one of us (QDN), she was a 22-year-old girl of normal intelligence, $149 \mathrm{~cm}$ tall, weighing $45 \cdot 5 \mathrm{~kg}$. No signs of Turner's syndrome could be observed. Gynaecological examination showed normal genitalia and a small uterus but no gonads could be felt on external examination. Axillary hair was normal, pubic hair was scanty, and the breasts were small. The patient did not complain of hot flushes or other signs of premature menopause. Endocrine findings, showing high gonadotrophin and low oestrogen values, are reported in table 2. Several courses of therapy with HCG (human chorionic gonadotrophin), HMG (human menopausal gonadotrophin), and clomiphene failed to induce 
TABLE 1 Cytogenetic data in cases of females with $X ; X$ translocation identified by banding techniques

\begin{tabular}{|c|c|c|c|c|}
\hline Authors & Clinical diagnosis & Sex chromatin & Karyotype & Inactive $X$ \\
\hline Distèche $e t a l^{3}$ & Signs of Turner's syndrome & $\begin{array}{l}\text { Large, bipartite } \\
\text { (OS and VS) }\end{array}$ & $46, X, X t$ (end to end fusion $\mathrm{p} 22: \mathrm{p} 22$ ) & Abnormal X \\
\hline Van den Berghe et al ${ }^{15}$ & Turner's syndrome & Rather large & $45, X / X, X t$ (Xp Xq) & Abnormal X \\
\hline Therman et als & Ovarian dysgenesis & $\begin{array}{l}\text { Large, bipartite } \\
\text { (OS and fibroblasts) }\end{array}$ & $46, X, X t(p t e r \rightarrow q 27:: q 27 \rightarrow$ pter $)$ & Abnormal \\
\hline $\begin{array}{ll}\text { Kim et al } & \begin{array}{l}\text { Mother } \\
\text { Daughter }\end{array}\end{array}$ & $\begin{array}{l}\text { Few Turner's stigmata } \\
\text { Many Turner's stigmata }\end{array}$ & $\begin{array}{l}\text { Large } \\
\text { Large }\end{array}$ & $\begin{array}{l}\text { 45,X/46,X,Xt(qter } \rightarrow \text { p22::p22 } \rightarrow \text { qter }) \\
46, X, X t(q t e r \rightarrow \text { p22::p22 } \rightarrow \text { qter })\end{array}$ & $\begin{array}{l}\text { Abnormal } \mathbf{X} \\
\text { Abnormal } \mathbf{X}\end{array}$ \\
\hline Ruthner and Golob16 & Gonadal dysgenesis & Very large & $45, X / 46, X, X t(p:: p)$ & \\
\hline Laurent et al ${ }^{17}$ & & & $46, X, X t(q t e r \rightarrow p 22:: q 12 \rightarrow$ pter $)$ & Abnormal $>$ \\
\hline Fraisse et al 18 & Signs of Turner's syndrome & Single and double masses & $46, X, X t(t e l o m e r i c$ fusion $\mathrm{p}:: \mathrm{p})$ & Abnormal X \\
\hline Sillesen et al ${ }^{19}$ & Turner's syndrome & $\begin{array}{l}\text { Normal, large, bipartite, } \\
\text { tripartite }\end{array}$ & $45, X / 46, X$, idicX(qter $\rightarrow$ p22: $:$ p22 $\rightarrow$ qter $)$ & Abnormal Y \\
\hline Sinha et al ${ }^{20}$ & & Very large & $45, X / 46, X, X t$ (end to end fusion $q:: q$ ) & Abnormal X \\
\hline $\begin{array}{l}\text { Mirzayants and } \\
\text { Baranovskaya21 }\end{array}$ & Gonadal dysgenesis & Very large & $45, X / 46, X, X t(q 27:: q 27)$ & Abnormal \\
\hline de la Chapelle et al 7 & Pure gonadal dysgenesis & & $\begin{array}{l}45, X / 46, X, X t(\text { pter } \rightarrow q 21:: q 11 \text { or } \\
\text { q13 } \rightarrow \text { pter })\end{array}$ & Abnormal $\mathbf{X}$ \\
\hline Laća et al 22 & Pure gonadal dysgenesis & Large & $45, X / 46, X, X t(q 24:: q 24)$ & Abnormal $>$ \\
\hline Our case & Ovarian dysgenesis & $\begin{array}{l}\text { Normal, large, bipartite, } \\
\text { double (OS and fibro- } \\
\text { blasts) }\end{array}$ & $46, X, X t(q t e r \rightarrow p 221:: p 223 \rightarrow$ qter) & Abnormal X \\
\hline
\end{tabular}

TABLE 2 Clinical, anatomical, and functional data in female patients with $X ; X$ translocation identified by banding techniques

\begin{tabular}{|c|c|c|c|c|c|c|c|c|c|c|c|c|c|c|c|c|}
\hline \multirow[t]{2}{*}{ Authors } & \multirow[t]{2}{*}{ Age } & \multicolumn{3}{|c|}{ Clinical features } & \multicolumn{4}{|c|}{ Gonads } & \multicolumn{2}{|l|}{ Genitalia } & \multicolumn{2}{|c|}{$\begin{array}{l}\text { Secondary } \\
\text { sex charac- } \\
\text { teristics }\end{array}$} & \multicolumn{4}{|c|}{ Hormonal studies } \\
\hline & & 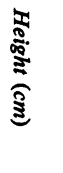 & 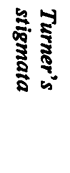 & 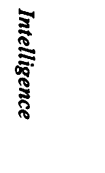 & : & 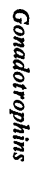 & 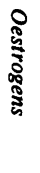 & 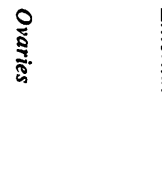 & 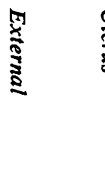 & $\underset{\mathfrak{s}}{\mathfrak{5}}$ & 龸 & $\stackrel{2}{\stackrel{2}{2}}$ & $\underset{y}{\grave{x}}$ & $\stackrel{2}{2}$ & ڤ్ & 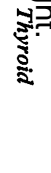 \\
\hline Distèche et $a l^{3}$ & 15 & 128 & + & Low & PA & $\uparrow$ & $\downarrow$ & & Inf & Small & - & - & $\mathbf{N}$ & $\mathbf{N}$ & & $\mathbf{N}$ \\
\hline Van den Berghe et al ${ }^{15}$ & 14 & 130 & + & & PA & $\mathbf{N}$ & $\downarrow$ & $\begin{array}{l}\text { Streaks, no } \\
\text { germ cells }\end{array}$ & Normal & Small & - & & & & & $\mathbf{N}$ \\
\hline Therman et als & 31 & 182 & & & PA & $\uparrow$ & & Streaks & Inf & Small & - & \pm & $\mathbf{N}$ & & & \\
\hline $\begin{array}{ll}\text { Kim et al } & \begin{array}{l}\text { Mother } \\
\text { Daughter }\end{array}\end{array}$ & $\begin{array}{l}34 \\
16\end{array}$ & $\begin{array}{l}152 \\
147\end{array}$ & $\begin{array}{l} \pm \\
+\end{array}$ & Normal & $\begin{array}{l}\text { SA } \\
\text { SA }\end{array}$ & $\uparrow$ & & & Normal & $\begin{array}{l}\text { Normal } \\
\text { Small }\end{array}$ & + & $\begin{array}{l}+ \\
\pm\end{array}$ & $\mathbf{N}$ & $\mathbf{N}$ & & \\
\hline Ruthner and Golob16 & 25 & 153 & \pm & & PA & $\uparrow$ & & $\begin{array}{l}\text { Streaks, no } \\
\text { germ cells }\end{array}$ & & Normal & + & + & & & & \\
\hline Laurent et al17 & 24 & 153 & & Normal & SA & & & & Normal & Normal & & & & & & \\
\hline Fraisse et al ${ }^{18}$ & 53 & 137 & + & Low & PA & $\uparrow$ & & & Inf & Normal & + & + & $\mathbf{N}$ & $\mathbf{N}$ & $\mathbf{N}$ & $\mathbf{N}$ \\
\hline Sillesen et al 19 & 11 & 124 & \pm & Normal & & $\uparrow$ & $\downarrow$ & & Normal & & - & - & & & & \\
\hline Sinha et $a l^{20}$ & 15 & & & & PA & & & & & & & & & & & \\
\hline $\begin{array}{l}\text { Mirzayants and } \\
\text { Baranovskaya21 }\end{array}$ & 23 & 173 & & & PA & $\uparrow$ & & & Normal & Small & + & \pm & $\mathbf{N}$ & $\mathbf{N}$ & $\mathbf{N}$ & $\mathbf{N}$ \\
\hline de la Chapelle et $a l^{7}$ & 18 & 158 & - & & PA & & $\downarrow$ & $\begin{array}{l}\text { Streak at } \\
\text { right, left } \\
\text { absent }\end{array}$ & Inf & Small & + & \pm & & & & \\
\hline Laca et $a l^{22}$ & 29 & 153 & & Low & PA & $\uparrow$ & & & & Small & + & & $\mathbf{N}$ & $\mathbf{N}$ & $\mathbf{N}$ & \\
\hline Our case & 22 & 149 & - & Normal & SA & $\uparrow^{*}$ & $\downarrow$ & $\begin{array}{l}\text { Streaks } \\
\text { bilaterally, } \\
\text { few primordia } \\
\text { follicles }\end{array}$ & $\begin{array}{l}\text { Normal } \\
\text { ial }\end{array}$ & Small & + & \pm & $\mathbf{N}$ & $\mathbf{N}$ & $\mathbf{N}$ & $\mathbf{N}$ \\
\hline
\end{tabular}

*Radioimmunoassay of serum gonadotrophin levels: HPRL $=15 \mathrm{ng} / \mathrm{ml}, \mathrm{FSH}=70 \mathrm{mIU} / \mathrm{ml}, \mathrm{LH}=147 \mathrm{mIU} / \mathrm{ml}$.

$\mathbf{N}=$ normal values. $\uparrow=$ high values. $\downarrow=$ low values. PA = primary amenorrhoea. $\mathbf{S A}=$ secondary amenorrhoea. Inf $=$ infantile. 
menstruation. A mini laparotomy performed in April 1979 showed a small uterus and very small streak gonads. Histological examination of the gonadal biopsy showed ovarian stroma, few primordial follicles, and hypertrophy of interstitial cells. No corpora lutea were observed.

A clinical diagnosis of ovarian dysgenesis ${ }^{8}$ was therefore made. On the basis of functional studies this case can also be classified as 'premature ovarian failure'. ${ }^{9}$

\section{CYTOGENETIC STUDIES}

Sex chromatin studies were performed on buccal mucosa smears and on fibroblast cultures after thionine staining. ${ }^{10}$ Chromosome analysis was performed by standard methods on leucocyte

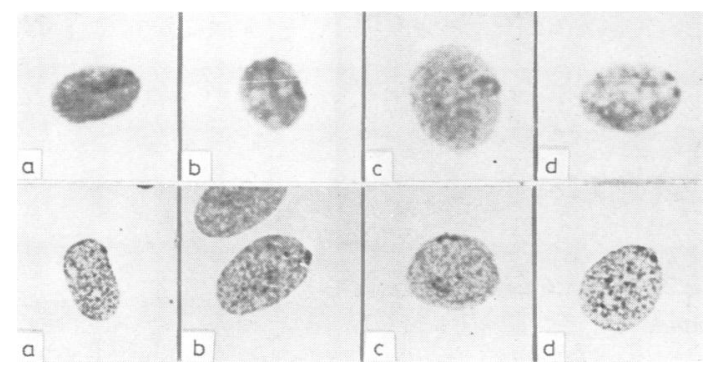

FIG 1 Sex chromatin in cells from oral smears (upper row) and fibroblasts (lower row): (a) normal sized single mass, (b) large single mass, (c) bipartite mass, $(d)$ double masses. cultures from the proband and her parents and on tissue cultures from ovarian biopsy of the proband. Tissue cultures were set up in a $\mathrm{CO}_{2}$ incubator and cultured in Ham's F10 medium (Difco) supplemented with $20 \%$ fetal calf serum (Gibco).

Standard chromosome preparations were stained with Giemsa or aceto-orcein. The following banding techniques were used: $Q$ banding with quinacrine mustard (QM, Sigma), modified C banding, ${ }^{11}$ and $R$ banding with acridine orange ${ }^{12}$ or modified Giemsa staining ${ }^{13}$ on cultures treated for 7 hours with BUdR (final concentration $200 \mu \mathrm{g} / \mathrm{ml}$ ).

Replication studies were performed on cells from both tissues labelled with ${ }^{3} \mathrm{HTdR}$ (final concentration $0.5 \mu \mathrm{Ci} / \mathrm{ml}$ ) or treated with BUdR (final concentration $200 \mu \mathrm{g} / \mathrm{ml}$ ) for the last 7 hours of culture.

Autoradiography was performed with Kodak stripping film AR 10. The emulsion coated slides were exposed in the dark at $4^{\circ} \mathrm{C}$ for 5 days.

The analysis of breakpoints was performed on leucocyte and fibroblast cultures treated with BUdR in a final concentration of either $200 \mu \mathrm{g} / \mathrm{ml}$, to obtain highly despiralised late replicating $\mathrm{X}$ chromosomes, or $100 \mu \mathrm{g} / \mathrm{ml}$ to obtain banded but less despiralised late $\mathrm{X}$ chromosomes.

\section{Results}

Sex chromatin bodies were observed in $38 \%$ of buccal mucosa cells and in $53 \%$ of the fibroblasts.

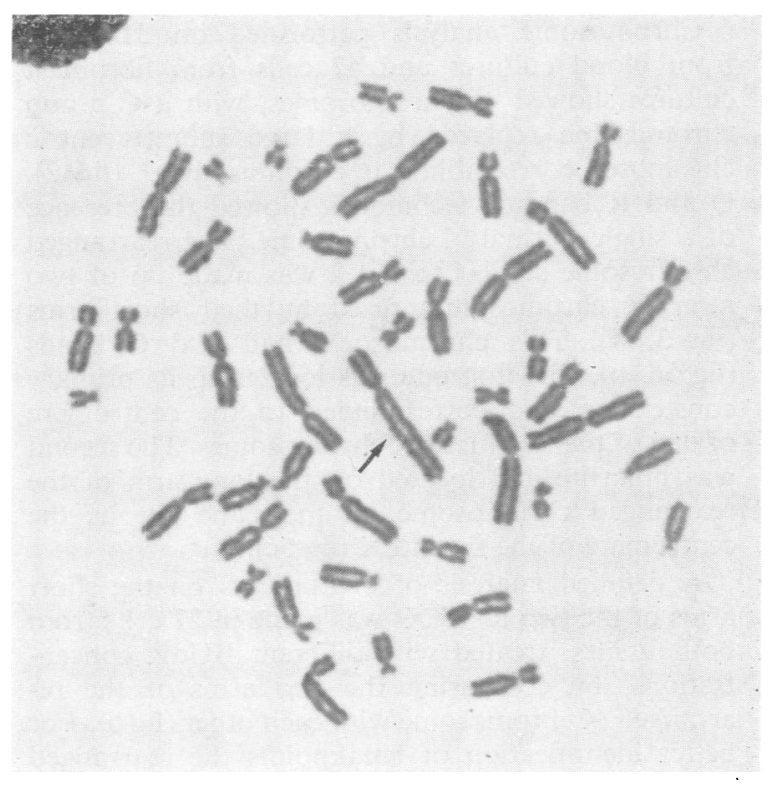

FIG 2 Giemsa stained cell from the proband. The arrow indicates the abnormal chromosome. 


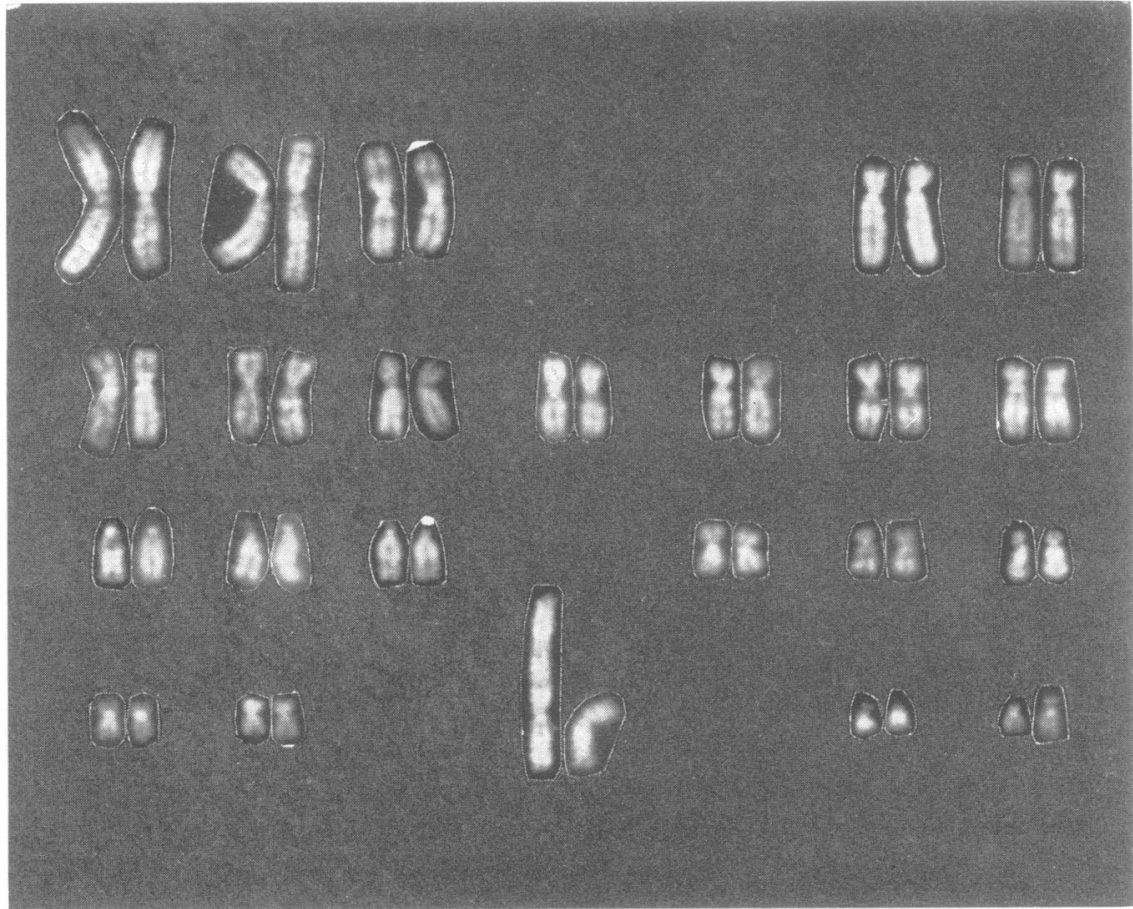

FIG $3 Q$ banded karyotype from leucocyte cultures of the proband.

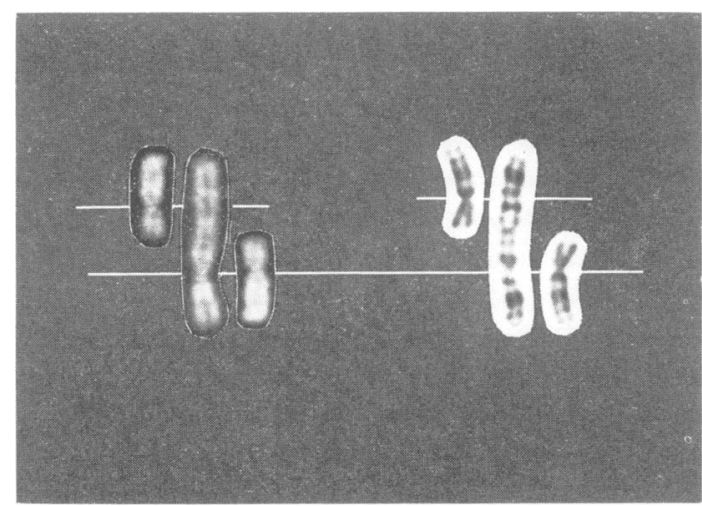

FIG 4 Identification of the abnormal chromosome.

Composite partial karyotype showing $Q$ banded (left) and $R$ banded (BUdR $100 \mu \mathrm{g} / \mathrm{ml}$, right) normal and rearranged $X$ chromosomes. The rearranged chromosome is compared to the normal $X$ (printed in duplicate) from the same cell. The line indicates the centromeres.

About one third of chromatin positive cells from both tissues showed a single, normal sized mass, often darkly stained (fig 1a). The other two thirds showed a very large, more faintly stained, single mass (fig 1b), or a large bipartite mass (fig 1c), of two normal sized masses with medium intensity of staining, always located close to each other (fig 1d).

Chromosome analysis performed on 316 cells $\overrightarrow{\vec{P}}$ from blood cultures and 47 cells from fibroblast cultures showed 46 chromosomes, with a $\mathrm{C}$ group $\bar{P}$ chromosome replaced by a large submetacentric chromosome resembling a chromosome 2 (fig 2). $Q$ and $\mathbf{R}$ banding techniques showed the presence of a single normal $\mathrm{X}$ chromosome. The rearranged $\dot{0}$ chromosome similar to No 2 was made up of two more $\mathrm{X}$ chromosomes fused by their short arms (fig 3, 4). This chromosome had two $\mathrm{C}$ bands (fig $5 \mathrm{a}, \mathrm{b}$ ). The first one was located in its primary $\mathrm{O}$ constriction and corresponded to the centromere of one of the two fused $\mathrm{X}$ chromosomes. The second was bipartite and located on the long arm of the rearranged chromosome, at the same site as the or centromere of the second $X$ (fig $5 \mathrm{c}$ ).

A detailed analysis of breakpoints on the short $\underset{\mathrm{C}}{\mathcal{N}}$ arms of the two fused Xs was made in 27 cells from 0 both tissues, treated with different BUdR concen- 0 trations, by comparing the two arms of the re- $\frac{D}{\Phi}$ arranged X chromosome with each other (fig 6). For $\stackrel{9}{+}$ better identification of breakpoints the rearranged 0 

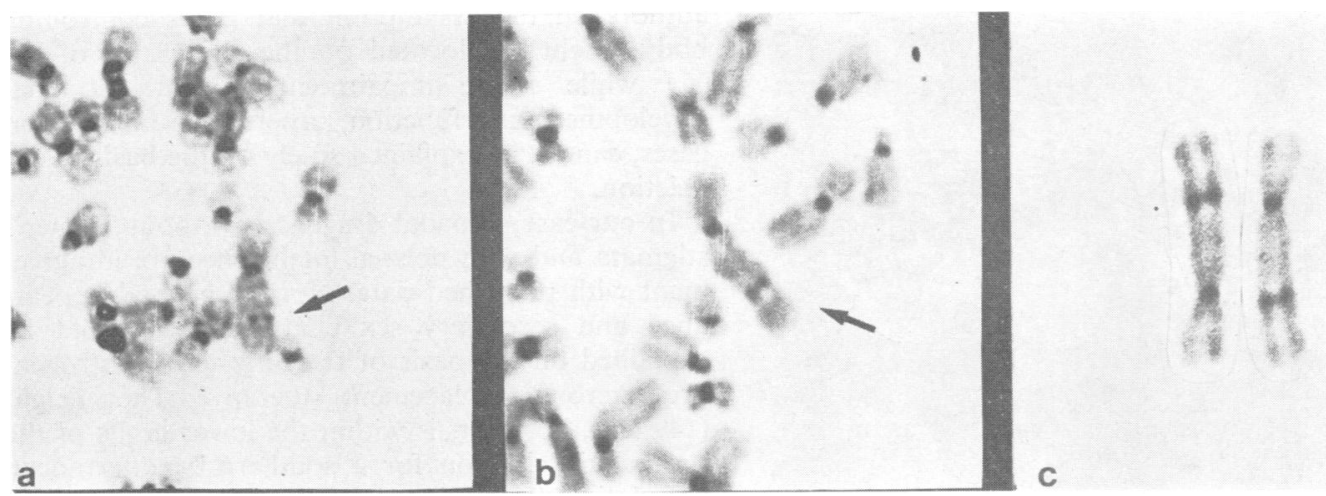

FIG 5 C bands in cells from fibroblast (a) and leucocyte (b) cultures. The arrows indicate the rearranged chromosome showing two $C$ bands. The bipartite $C$ band is located at the same site as the centromere of the second $X(c)$.

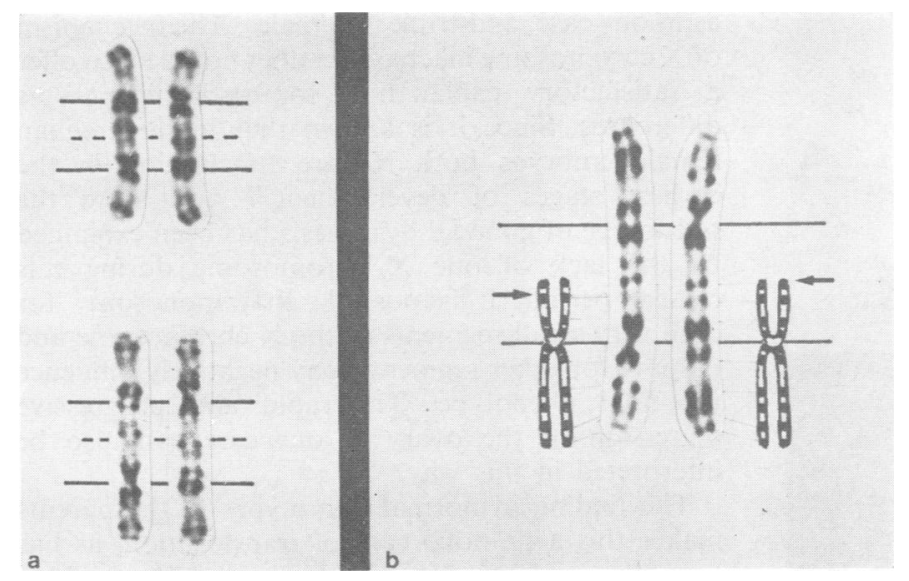

FIG 6 Identification of the breakpoints in the short arms of the fused $X$ chromosomes:

(a) comparison between the two arms of the rearranged chromosome (printed twice) from two different cells $(B U d R, 200 \mu \mathrm{g} / \mathrm{ml})$; (b) comparison of the two arms of the rearranged chromosome with each other and with the diagram of late-replicating $X$ (BUdR, $100 \mu \mathrm{g} / \mathrm{ml})$. The solid line indicates the centromeres, the dotted line the fusion sites. The arrows indicate the breakpoints.

chromosome was also compared with a standard $\mathbf{R}$ banding scheme of a late replicating $X^{14}$ The results show that the chromosome with a single $\mathrm{C}$ band is broken in sub-band 221 , and the other, with a bipartite $\mathrm{C}$ band, in band 223 (fig 6 b).

The rearranged chromosome has therefore been characterised as $46, X, \operatorname{dic}(X)(\mathrm{qter} \rightarrow \mathrm{p} 221:: \mathrm{p} 223 \rightarrow$ qter). ${ }^{4}$ The patient is therefore trisomic for Xqter $\rightarrow$ p221, disomic for $\mathrm{p} 222 \rightarrow \mathrm{p} 223$, and monosomic for p223 $\rightarrow$ pter.

Replication studies on 270 cells from the two tissues showed that the rearranged chromosome was always preferentially inactivated with respect to the normal X chromosome, both in ${ }^{3} \mathrm{HTdR}$ and in BUdR treated cells (fig 7). Sex chromatin and chromosome findings in our case and other published cases are reported in table 1 . The karyotypes of both parents were normal.

\section{Discussion}

All available clinical and chromosomal findings on cytologically well documented $\mathrm{X} ; \mathrm{X}$ translocations are shown in tables 1 and 2.

In all cases with complex $\mathrm{X}$ chromosome rearrangements the difficulty in establishing causeeffect relationships between chromosome constitution and the final phenotype also results from the frequently observed mosaicism with coexistence of an XO cell line, and from the complex mechanisms of selective cell growth and $\mathrm{X}$ chromosome inactivation. Some general evidence may be tentatively drawn from published reports.

It can be seen from table 1 that one constant feature is ovarian dysgenesis with or without Turner's stigmata, resulting in primary or secondary amenorrhoea, high values of gonadotrophins, and 

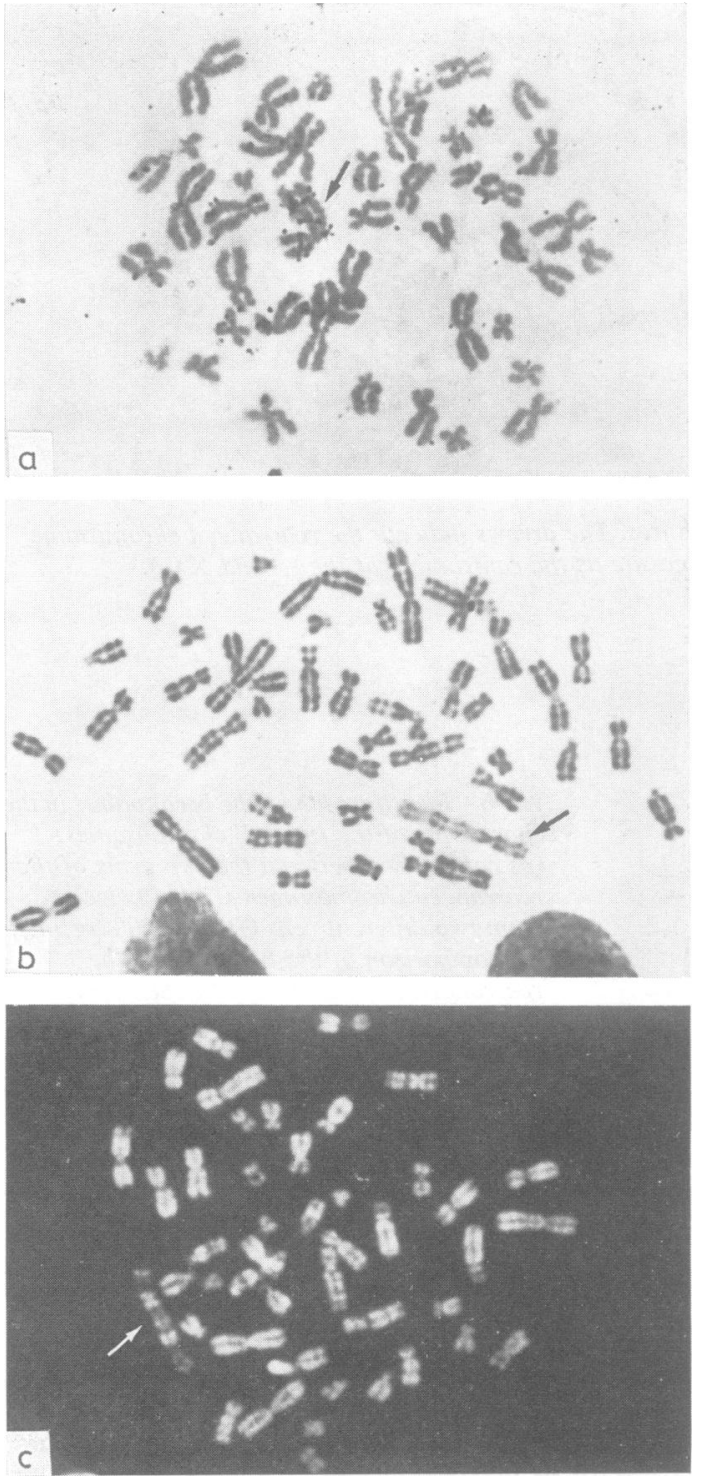

FIG 7 Preferential inactivation of the rearranged chromosome (arrowed): (a) labelling with ${ }^{3} H T d R,(b)$ Giesma staining after $200 \mu \mathrm{g} / \mathrm{ml} B U d R,(c)$ acridine orange staining after $200 \mu \mathrm{g} / \mathrm{ml} B U d R$.

the presence of streak ovaries. Another fairly constant feature in cases of $\mathrm{Xp}$ deletion is small stature, which is lower than the average population height. In fact, it emerges from table 1 that only those subjects carrying deletions of the long arm of the $\mathrm{X}$ chromosome are of average, or higher than average, stature. Short stature has been explained by some authors on the assumption that genes controlling body height are located on the short arm of the $\mathrm{X},{ }^{7}$ while severe impairment of both gonadal development and function, observed in all deletion $\Rightarrow$ cases, cannot be explained solely on the basis of $\mathrm{Xp} \stackrel{\text { ? }}{\mathrm{C}}$ deletion.

In our case, gonadal dysgenesis without Turner'soㅡㅡㄹ stigmata and with normal intelligence are in agree- $\frac{\bar{p}}{\bar{D}}$ ment with published data. Normal general appear- $-\mathbb{D}$ ance and secondary sex characteristics could beo explained on the basis of the long term oestrogen- progesterone replacement therapy. The height. $(149 \mathrm{~cm})$, however, is within the lower limits of the $\vec{\omega}$ normal distribution for a southern Mediterraneans population. This might be related to the cytological 3 demonstration of monosomy for only a minute segment of Xp (p223 $\rightarrow$ pter).

There are striking phenotypic differences between non-mosaic females with almost total $X$ trisomy, as in our case, and triple $X$ females. The mechanism of $\mathrm{X}$ chromosome inactivation does not seem to offer a satisfactory explanation for their phenotypic ${ }_{\square}^{-}$ differences. Since it is known that in mammalian® female embryos both Xs are functioning in the earliest stages of development, ${ }^{23}$ and since the $\frac{3}{0}$ phenotype of gonadal dysgenesis has been explained $\stackrel{\mathbb{S}}{-}$ by the lack of one $\mathrm{X}$ chromosome during this $\overrightarrow{0}$ critical period, it is possible that monosomy for even very small segments of the $X$ chromosome and trisomy for other segments may negatively influerees the final phenotype. The rapid and progressive regression of the ovary in our case can also be interpreted in this way.

The finding of normal karyotypes in the parents makes this a de novo case of translocation, as haso를 been observed in most published cases. The analysis 3 of banding patterns in BUdR treated cells showed that the breakpoints are located in two different sub-bands (p221 and p223, respectively) in the two X chromosomes (fig 6). It follows that the translocation? must have arisen from an asymmetrical break occurring either during premeiotic $G_{1}$ in the two $X_{-}^{-}$ chromosomes in the maternal germ line, or in $\mathrm{G}_{2}$ 국 in the sister chromatids of the $\mathrm{X}$ in either the maternal or the paternal germ line. This seems to be? the most reasonable explanation on cytological grounds. Furthermore a symmetrical location of breakpoints would also imply a second, interstitial, N deletion in band p221 of the acentric X chromosome (fig 6). Both these mechanisms, as well as other more complex ones which could be proposed, call for anc early inactivation of one of the centromeres of the rearranged chromosome. In fact, an essentialo condition for cell survival is that one of the centromeres becomes inactive. This does not necessarily? imply the existence of a cause-effect relationship $\frac{T}{0}$ 
between the two events of translocation and centromeric inactivation.

Replication studies have shown that the rearranged chromosome is always preferentially inactivated. This finding is in agreement with data obtained by other authors. Sex chromatin results are also in agreement with published data (table 1). The finding of a single, normal sized, deeply stained sex chromatin mass in about one-third of cells can be explained by different degrees of heteropyknosis in different cells. The same large rearranged $\mathrm{X}$ chromosome may therefore appear, according to the degree of condensation and possibly to the phase of the cell cycle, as a single heavily stained mass, a single large faintly-stained mass, a bipartite mass, or two single masses.

Replication studies have shown preferential inactivation of the rearranged chromosome in two tissues, leucocytes and fibroblasts, both having the same embryological (mesodermal) origin. It can be inferred, on the basis of the results obtained by sex chromatin studies on buccal smears, that another tissue of different (ectodermal) origin, that is, oral mucosa, must also have the same chromosomal complement and the same preferential inactivation of the rearranged $\mathrm{X}$ chromosome.

\section{References}

1 Kim HJ, Hsu LYF, Hirschhorn K. Familial X/X translocation t (X;X) (p22;q13). Cytogenet Cell Genet 1974; 13:454-64.

2 Gouw WL, Coenegracht JM, Stalder G. A very large metacentric chromosome in a woman with symptoms of Turner's syndrome. Cytogenetics 1964;3:427-40.

3 Distèche A, Hagemeijer A, Frederic J, Progneaux D. An abnormal large human chromosome identified as an end to end fusion of two X's by combined results of the new banding techniques and microdensitometry. Clin Genet $1972 ; 3: 388-95$.

4 Paris Conference. Standardization in human cytogenetics. Birth Defects $1971 ; 8$ :No.7.

5 Therman E, Sarto GE, Patau K. Apparently isodicentric but functionally monocentric $\mathrm{X}$ chromosome in man. Am J Hum Genet 1974;26:83-92.

6 Therman E, Patau K. Abnormal $X$ chromosomes in man : origin, behavior and effects. Humangenetik 1974;25: $1-16$.

7 de La Chapelle A, Gronman P, Latt SA. Multiple cytogenetic methods used to identify a new structural rearrangement of the human $\mathrm{X}$ chromosome. Cytogenet Cell Genet 1978;20:204-12.
8 Polani PE. Chromosomes phenotypes-sex chromosomes. Proceedings of the 3rd International Conference on Congenital Malformations, The Hague, 7-13 September, 1969.

9 Johnson TR, Peterson EP. Gonadotropin-induced pregnancy following 'premature ovarian failure'. Fertil Steril $1979 ; 31: 351$.

10 Klinger HP, Ludwig KS. A universal stain for the sex chromatin body. Stain Technol 1957;32:235-44.

11 Sumner AT. A simple technique for demonstrating centromeric heterochromatin. Exp Cell Res 1972;75: 304-6.

12 Dutrillaux B, Laurent C, Couturier J, Lejeune J. Coloration des chromosomes humains par l'acridine orange après traitment par le 5-bromodeoxyuridine. $C R$ Acad Sci $[$ D] (Paris) 1973;276:3179-81.

13 Perry P, Wolff S. New Giemsa method for the differential staining of sister chromatids. Nature 1974;251:156-8.

14 Biemont MC, Laurent C, Couturier J, Dutrillaux B. Chronologie de la réplication des bandes des chromosomes sexuels dans les lymphocytes de sujets normaux et anormaux. Ann Genet (Paris) 1978;21:133-41.

15 Van den Berghe H, Soyez C, Fryns JP. X/X translocation in a patient with Turner's syndrome. Humangenetik 1973; 20:377-80.

16 Ruthner U, Golob E. Fusion of the short arms of one X chromosome in a patient with gonadal dysgenesis. Humangenetik 1974;24:159-60.

17 Laurent C, Biemont MC, Dutrillaux B. Sur quatre nouveaux cas de translocation du chromosome $\mathrm{X}$ chez l'homme. Humangenetik 1975;26:35-46.

18 Fraisse J, Laurent C, Collard N, Biemont MC, Dutrillaux B. Un deuxième example de fusion télomérique de deux chromosomes X. Ann Genet (Paris) 1975;18:243-5.

19 Sillesen I, Rasmussen K, Østerballe O, Nielsen J. Center for Barr body condensation. A case of Turner's syndrome with $45, X / 46, X$, dic (X) (Xqter $\rightarrow$ p 22::p22 $\rightarrow$ qter). Hum Genet 1976;33:337-40.

20 Sinha AK, Pathak S, Nora J. Fusion of two apparently intact human chromosomes. Hum Genet 1976;32:295-300.

21 Mirzayants GC, Baranovskaya LI. X-X translocation in a patient with gonadal dysgenesis and the problem of phenotype-karyotype correlation. Hum Genet 1978;40: 249-57.

22 Laća Z, Ivanović $M$, Dramušic V, Morić-Petrović S Isodicentric $\mathrm{X}$-chromosome in a woman with characteristics of gonadal dygenesis. Hum Genet 1979;40: 237-41.

${ }^{23}$ Epstein CJ, Smith S, Traviv B, Tacker G. Both X chromosomes function before visible $\mathrm{X}$-chromosome inactivation in female mouse embryos. Nature 1978;274:500-2.

Requests for reprints to Dr A de Capoa, Istituto di Genetica, Facolta di Scienze, Citta Universitaria, 00185 Rome, Italy. 